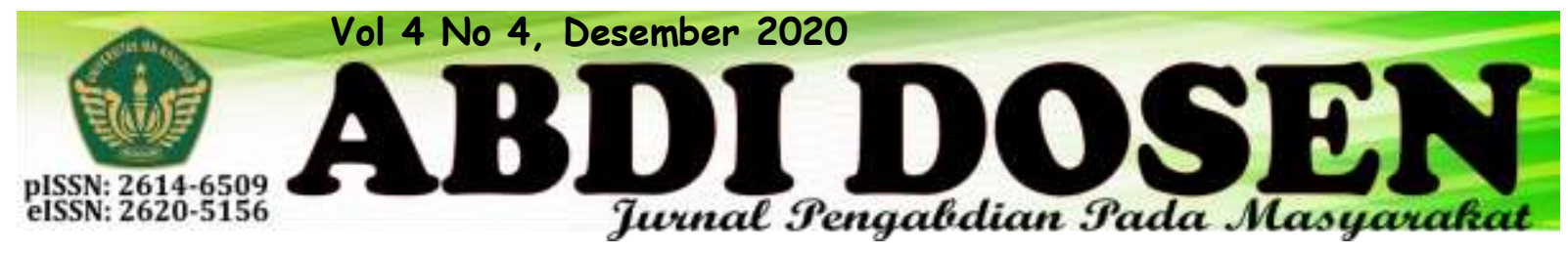

\title{
PEMBERDAYAAN MASYARAKAT MELALUI WORKSHOP EKONOMI KREATIF BERBASIS PROMOSI ONLINE OLAHAN SINGKONG DI UKM KELOMPOK TANI GENTING JAYA BENGKULU UTARA
}

\author{
Herman Lusa ${ }^{1}$, Irfan Supriatna ${ }^{2}$ \\ hermandatuk1005@gmail.com ${ }^{1}$ \\ irfansupriatna@unib.ac.id ${ }^{2}$ \\ Universitas Bengkulu, Jalan WR. Supratman, Kandang Limun, Bengkulu ${ }^{12}$
}

\begin{abstract}
ABSTRAK
Pemberdayaan masyarakat tidak hanya semata-mata memenuhi kebutuhan dasar masyarakat tetapi lebih sebagai upaya mencari alternative pertumbuhan ekonomi lokal. Dalam rangka meningkatkan percepatan pembangunan di wilayah Kabupaten Bengkulu Utara pada umumnya dan khususnya di Desa Padang Bendar Kecamatan Hulu Palik pada khususnya, Universitas Bengkulu dalam hal ini Fakultas Keguruan dan Ilmu Pendidikan (FKIP) melakukan salah satu bentuk pengabdian kepada masyarakat untuk dapat ikut berpartisipasi dalam membangun desa atau UKM. Pemberdayaan masyarakat dalam meningkatkan SDM melalui workshop ekonomi kreatif berbasis promosi online olahan singkong. Ekonomi kreatif merupakan proses peningkatan nilai tambah hasil produk yang dijual yaitu pengolahan keripik singkong yang awalnya hanya menggunakan pisau untuk mengiris sekarang sudah menggunakan alat pengiris serbaguna yang lebih efektif dan sudah gunakan mesin press dan stiker brand keripik, kemasan lebih menarik dan memiliki aneka varian rasa. Produksi dan penghasilan UKM juga semakin meningkat karena promosi online melalui $\mathrm{Fb}$, IG, dan WA membuat jangkauan pembeli makin luas.
\end{abstract}

Kata kunci: Pemberdayaan masyarakat, ekonomi kreatif, online

\begin{abstract}
Community empowerment is not only fulfilling the basic needs of the community but more as an effort to find alternatives to local economic growth. In order to increase the acceleration of development in the North Bengkulu Regency area in general and in particular in Padang Bendar Village, Hulu Palik District in particular, the University of Bengkulu, in this case the Teacher Training and Education Faculty (FKIP), is doing one form of community service to be able to participate in building village or UKM. Community empowerment in improving human resources through creative economy workshops based on online promotion of processed cassava. The creative economy is a process of increasing the added value of products sold, namely the processing of cassava chips, which initially only used a knife to slice, now uses a multipurpose slicer which is more effective and has used a press machine and chip brand stickers, the packaging is more attractive and has various flavors. The
\end{abstract}


production and income of UKM is also increasing because online promotion through $F B, I G$ and WA has made the reach of buyers even wider.

\section{Keywords: Community empowerment, creative economy, online}

\section{PENDAHULUAN}

Desa Padang Bendar berada di Kecamatan Hulu Palik dengan luas wilayah 162,41KM2 yang terdiri dari 17 (tujuh belas) desa dan kelurahan. Dengan jumlah penduduk 35.651 jiwa (Tahun 2006) dengan kepadatan $145,63 / \mathrm{Km}^{2}$. Jarak Lubuk Durian dengan pusat kota Arga Makmur $27 \mathrm{Km}$, dan dengan pusat ibu kota provinsi $49 \mathrm{Km}$ dengan ketinggian $250 \mathrm{M}$ Dpl dengan suhu rata-rata $28^{\circ} \mathrm{C}$.

Melihat secara geografis Desa Padang bendar yang berada di Pemerintah Bengkulu Utara mempunyai visi Terwujudnya Pemerintahan Yang Adil Untuk Kesejahteraan Rakyat. Upaya mencapai visi tersebut Pemerintah Bengkulu Utara berupaya melakukan beberapa terobosan dan pembenahan di berbagai bidang tidak terkecuali bidang SDM dan ekonomi kreatif sesuai dengan misi dari Kabupaten Bengkulu Utara yaitu membangun sumber daya manusia dan membangun ekonomi kerakyatan.

Dalam rangka meningkatkan percepatan pembangunan di wilayah Kabupaten Bengkulu Utara pada umumnya dan khususnya di Desa Padang Bendar Kecamatan Hulu Palik pada khususnya, Universitas Bengkulu dalam hal ini Fakultas Keguruan dan Ilmu Pendidikan (FKIP) melakukan salah satu bentuk pengabdian kepada masyarakat untuk dapat ikut berpartisipasi dalam membangun desa-desa atau UKM dengan pemberdayaan masyarakat.

Kegiatan PPM juga merupakan wujud nyata dari kepedulian perguruan tinggi dalam melaksanakan misinya membantu mengatasi permasalahan kemasyarakatan, pembangunan dan pembinaan lingkungan dengan karya dan bukti nyata.

Musyawarah Perencanaan Pembangunan Perubahan kedua Rencana Pembangunan Daerah (RPJMD) Kabupaten Bengkulu Utara Tahun 20162022, Pemkab Bengkulu Utara akan fokus pada pembangunan dan kesejahteraan masyarakat.

Desa Padang bendar Kecamatan Hulu Palik sebagai salah satu kabupaten yaitu Bengkulu Utara yang secara demografis banyak memiliki potensi, diantaranya bidang SDM, pertanian dan kewirausahaan (ekonomi kreatif) yang dapat dioptimalkan dalam usaha untukpembangunan desa untuk meningkatkan perekonomian masyarakat desa tersebut.

Salah satu potensi yang perlu dikembangkan yaitu yaitu pengembanganolahan singkong tersebut, namun selama ini belum ada penampung khusus," kata Kepala Camat Hulu Palik (Darmawan, S.Sos). Selain itu kendala pengembangan berbagai jenis singkong di daerah itu masih banyak hama babi hutan, sehingga petani kewalahan untuk menanamnya.

Masalah yang ditemukan beberapa permasalahan diantaranya: Pertama, dalam bidang SDM, dimana SDM perlu diberdayakan sehingga adanya peningkatan dalam mutu SDM, sehingga SDM di Desa Padang bendar pengelolaannya maksimal seperti, 
pelatihan ekonomi kreatif berbasis promosi online kemudian berkompeten sesuai bidangnya. Kedua, dalam bidang ekonomiwarga Desa Padang bendar belum bisa melihat atau membuka peluang usaha yang mana potensi yang ada di daerah tersebut adalah pengolahan makanan yang bisa dikembangkan menjadi salah satu mata pencaharian bagi mereka, yaitu dalam olahan singkong.

Menurut, Ketua Kelompok Tani Genting Jaya (Suharno) bahwa Desa Padang Bendar Kecamatan Hulu Palik memiliki potensi hasil pertanian yang cukup menjanjikan, salah satunya adalah singkong. Harga singkong atau ubi kayu di tingkat petani mencapai $\mathrm{Rp} 750$ per kilogram (kg) hingga Rp 850 per kg. Bahkan sejumlah negara di Asia banyak yang membutuhkan singkong, sehingga prospek untuk ekspor juga semakin besar.

Singkong jika diolah sebaik mungkin akan menghasilkan beragam olahan singkong yang dapat dimanfaatkan sebuah ekonomi kreatif yang mana dapat di kembangkan oleh UKM-UKM di daerah Bengkulu Utara khususnya di Desa Padang Bendar Kecamatan Hulu Palik.Berdasarkan analisis situasi dan permasalahan, maka rumusan masalah dalam pengabdian ini adalah pemberdayaan masyarakat melalui kegiatan workshop ekonomi kreatif berbasis promosi onlineuntuk meningkatkan pemberdayaan masyarakat di Kelompok Tani Genting Jaya Desa Padang Bendar Bengkulu Utara dan meningkatkan kemampuan mutu SDM untuk pemberdayaan masyarakat melalui ekonomi kreatif berbasis promosi online.

Dalam kajian ini pemberdayaan masyarakat (community empowerment) dan pembangunan masyarakat (community development) dimaksudkan sebagai pemberdayaan masyarakat yang sengaja dilakukan pemerintah untuk memfasilitasi masyarakat lokal dalam merencanakan, memutuskan dan mengelola sumberdaya yang dimiliki sehingga pada akhirnya mereka memiliki kemampuan dan kemandirian secara ekonomi, ekologi dan sosial secara berkelanjutan. Oleh karena itu pemberdayaan masyarakat pada hakekatnya berkaitan erat dengan sustainable development yang membutuhkan pra-syarat keberlanjutan kemandirian masyarakat secara ekonomi, ekologi dan sosial yang selalu dinamis.

Pemberdayaan masyarakat (Noor, 2011) adalah konsep pembanguan ekonomi yang merangkum nilai-nilai masyarakat untuk membangun paradigma baru dalam pembangunan yang bersifat peoplecentered, participatory, empowerment and sustainable (Chamber, 1995). Lebih jauh Chamber menjelaskan bahwakonsep pembangunan dengan model pemberdayaan masyarakat tidak hanya semata-mata memenuhi kebutuhan dasar (basic need) masyarakat tetapi lebih sebagai upaya mencari alternative pertumbuhan ekonomi lokal.

Pemberdayaan

masyarakat (empowerment) sebagai strategi alternative dalam pembangunan telah berkembang dalam berbagai literatur dan pemikiran walaupun dalam kenyataannya belum secara maksimal dalam implementasinya. Pembangunan dan pemberdayaan masyarakat merupakan hal banyak dibicarakan masyarakat karena terkait dengan kemajuan dan perubahan bangsa ini kedepan apalagi apabila dikaitkan dengan skill masyarakat yang masih kurang akan sangat menghambat pertumbuhan ekonomi itu sendiri

Empowerment (pemberdayaan masyarakat) adalah konsep pembangunan 
ekonomi yang merangkum nilai-nilai sosial dan mencerminkan paradigma baru dalampembangunan yang bersifat people centered participatory, empowering and sustainable (Chambers, 1995).

Dalam rangka mengemban tugas dalam bidang pemberdayaan masyarakat , Badan Pemberdayaan menetapkan visi, misi, kebijakan, strategi dan program pemberdayaan masyarakat sebagai berikut:

a) Visi Pemberdayaan Masyarakat adalah meningkatkan kemandirian masyarakat

b) Misi Pemberdayaan Masyarakat adalah mengembangkan kemampuan dan kemandirian dan secara bertahap masyarakat mempu membangun diri dan lingkungannya secara mandiri. Kemandirian dalam konsep pemberdayaan masyarakat yang dimaksud adalah tingkat kemajuan yang harus dicapai sehingga masyarakat dapat membangun dan memelihara kelangsungan hidupnya berdasarkan kekuatannya sendiri secara berkelanjutan, artinya untuk membangun bangsa yang mandiri dibutukan perekonomian yang mapan.

Ekonomi kreatif adalah penciptaan nilai tambah yang berbasis ide yang lahir dari kreativitas sumber daya manusia (orang kreatif) dan berbasis pemanfaatan ilmu pengetahuan, termasuk warisan

\section{METODE KEGIATAN}

Adapun metode kegiatan PPM dilakukan dengan cara deskriptif kualitatif dimulai sebagai berikut:

\section{a. Penetapan Lokasi PPM}

Penetapan lokasi ditentukan
berdasarkan
daerah yang sangat

budaya dan teknologi. Lebih lanjut didevinisikan Ekonomi kreatif atau dikenal juga dengan sebutan knowledge based economy merupakan pendekatan dan tren perkembangan ekonomi dimana teknologi dan ilmu pengetahuan memiliki peran penting di dalam proses pengembangan dan pertumbuhan ekonomi. Ekonomi kreatif dapat diartikan sebagai kumpulan aktivitas ekonomi yang terkait dengan penciptaan atau penggunaan pengetahuan dan informasi. Definisi menurut Institute For Development Economy and Finace (2005), ekonomi kreatif merupakan proses peningkatan nilai tambah hasil dari eksploitasi kekayaan intelektual berupa kreativitas, keahlihan, dan bakat individu menjadi sautu produk yang dapat dijual.

Ekonomi kreatif adalah sebuah konsep di era ekonomi baru yang mengintensifkan informasi dan kreativitas dengan mengandalkan ide dan pengetahuan dari sumber daya manusia sebagai faktor produksi yang utama. Dari beberapa definisi di atas dapat diartikan bahwa ekonomi kreatif adalah sebuah kegiatan ekonomi yang timbul dari adanya kreatifitas, di mana dari berbagai kreatifitas, inovasi, bakat, ide, gagasan, sebagai wujud nyata dari kreatif tersebut dan kekayaan intelektual merupakan sumber utama dari ekonomi kreatif. Melalui promosi online akan meningkatkan keterjangkauan promosi ke masyarakat lebih luas dan praktis.

berpotensi untuk dikembangkan SDM nya dalam bidang pertanian yaitu singkong di Daerah Padang Bendar Kecamatan Hulu Palik Bengkulu Utara.

b. Studi Pendahuluan Profil Masyarakat 
Setelah lokasi ditentukan peneliti PPM melakukan kegiatan studi pendahuluan mengetahui bagaimana situasi kondisi dan budaya yang ada pada lokasi pengabdian.

c. Pelaksanaan PPM

Pelaksanaan PPM di lapangan disusun berdasarkan permasalahan yang dihadapi masyarakat lokasi PPM yang telah disesuaikan dengan pengabdian dosen Fakultas Keguruan dan Ilmu Pendidikan (FKIP) Universitas Bengkulu melalui Pemberdayaan

\section{HASIL DAN PEMBAHASAN}

Pelaksanaan PPM workshop ekonomi kreatif berbasis promosi online untuk meningkatkan pemberdayaan masyarakat di Kelompok Tani Genting Jaya Desa Padang Bendar Bengkulu Utara dan meningkatan kemampuan mutu SDM untuk pemberdayaan masyarakat melalui ekonomi kreatif berbasis promosi online telah terlaksana dengan sukses. Masyarakat sangat antusias mengikuti kegiatan workshop dan merasakan masyarakat dalam meningkatkan SDM melalui workshop ekonomi kreatif berbasis promosi online olahan singkong.

d. Evaluasi Pelaksanaan

Evaluasi pelaksanaan dilaksanakan secara berkala dari proses studi pendahuluan, pelaksanaan dan evaluasi laporan akhir PPM.

e. Pelaporan PPM

Pelaporan PPM dilaksanakan secara autentik, obyektif, dan rasional.

langsung manfaatnya hingga usaha keripik mereka semakin berkembang. Tahapantahapan yang dilakukan dari awal sampai akhir yaitu diantaranya meninjau langsung perkebunan singkong, pelaksanaan workshop, tindak lanjut dari hasil workshop, dan terakhir promosi online melalui FB, IG, dan WA. Berikut ini kondisi sebelum dan sesudah kegiatan workshop dan tindak lanjut dari workshop PPM diadakan.

Tabel 1 Kondisi Sebelum Dan Sesudah PPM

\begin{tabular}{|l|l|}
\hline \multicolumn{1}{|c|}{ Sebelum Kegiatan Workshop PPM } & \multicolumn{1}{c|}{ Sesudah Kegiatan Workshop PPM } \\
\hline $\begin{array}{l}\text { Pengetahuan masyarakat masih sangat awam } \\
\text { mengenai ekonomi kreatif }\end{array}$ & $\begin{array}{l}\text { Pengetahuan masyarakat semakin bertambah } \\
\text { mengenai ekonomi kreatif }\end{array}$ \\
\hline $\begin{array}{l}\text { Masyarakat belum terampil dalam } \\
\text { pengemasan yang menarik }\end{array}$ & $\begin{array}{l}\text { Masyarakat sudah semakin terampil } \\
\text { mengemas keripiknya lebih menarik }\end{array}$ \\
\hline $\begin{array}{l}\text { Masyarakat belum mengerti cara promosi } \\
\text { online, dagangan keripiknya hanya dititip di } \\
\text { warung tetangga }\end{array}$ & $\begin{array}{l}\text { Masyarakat bertambah pengetahuan dan } \\
\text { keterampilannya dalam promosi berbasis } \\
\text { online }\end{array}$ \\
\hline $\begin{array}{l}\text { Alat produksi yang digunakan sangat } \\
\text { sederhana yaitu hanya pisau dan telenan }\end{array}$ & $\begin{array}{l}\text { Alat produksi yang digunakan lebih inovatif } \\
\text { yaitu Alat Pengiris serbaguna yang sangat } \\
\text { praktis dalam mengiris singkong }\end{array}$ \\
\hline $\begin{array}{l}\text { Kemasan keripik hanya menggunakan palstik } \\
\text { biasa dan tidak ada merk }\end{array}$ & $\begin{array}{l}\text { Kemasan keripik sudah lebih bagus yaitu } \\
\text { menggunakan palstik berbahan tebal dan ada } \\
\text { sticker merk yang menjadi brand }\end{array}$ \\
\hline $\begin{array}{l}\text { Alat membungkus kemasan keripik hanya } \\
\text { gunakan lilin untuk menempelkan plastik }\end{array}$ & $\begin{array}{l}\text { Alat membungkus kemasan keripik sudah } \\
\text { lebih canggih yaitu menggunakan mesin }\end{array}$ \\
\hline
\end{tabular}




\begin{tabular}{|l|l|}
\hline agar tidak bocor/masuk angin & Press otomatis \\
\hline Produksi keripik hanya sedikit & Produksi keripik semakin meningkat \\
\hline Usaha keripik konvensional & $\begin{array}{l}\text { Usaha keripik makin modern dan kreatif } \\
\text { dengan berbagai inovasi ragam varian rasa, } \\
\text { pengemasan yang bagus dan promosi online } \\
\text { yang membuat usaha semakin berkembang }\end{array}$ \\
\hline
\end{tabular}

Tahapan pertama dalam kegiatan ini melimpah,namun petani disana tidak tahu yaitu meninjau langsung perkebunan singkong, dimana perkebunan singkong yang ada di Desa Padang Bendar sangatlah mau diapakan hasil dari perkebunan tersebut. Berikut foto-foto saat tim PPM meninjau langsung perkebunan singkong.
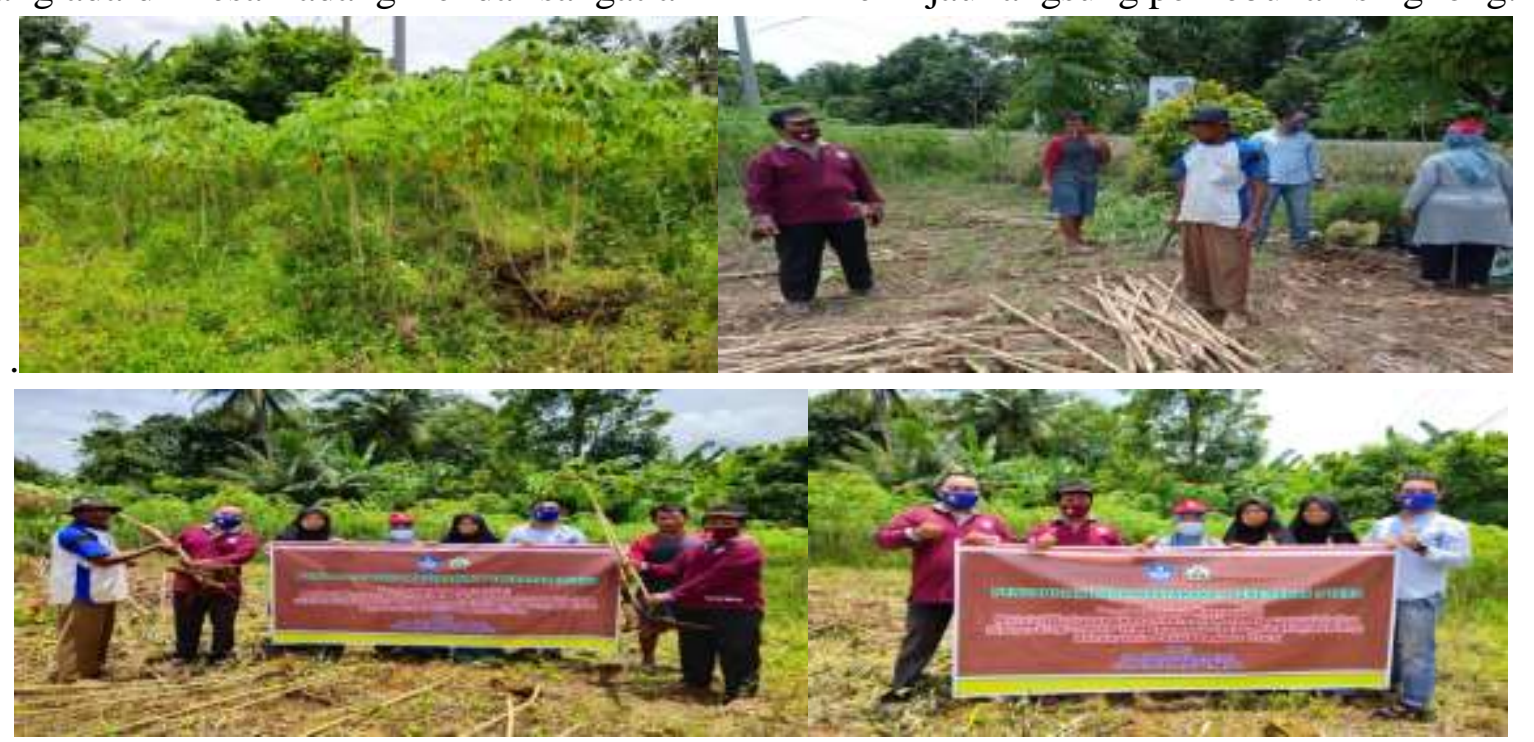

Gambar 1 Peninjauan Lokasi Perkebunan Singkong

Tahapan kedua yaitu pelaksanaan workshop, pelaksanaan ini dihadiri oleh para ibu-ibu yang berada di Desa Padang Bendar selaku petani singkong. Kegiatan ini dimulai dari memberikan materi dari tim PPM sekaligus membimbing bagaimana cara 4P yaitu Pengupasan,
Pengirisan, Pengemasan, dan Pemasaran. Dalam pelaksanaan workshop ini tentu kita mengikuti protokol kesehatan dengan selalu memakai masker, mencuci tangan dengan sabun sebelum memasuki ruangan, dan menjaga jarak. Berikut foto-foto yang diambil pada saat pelaksanaan workshop. 


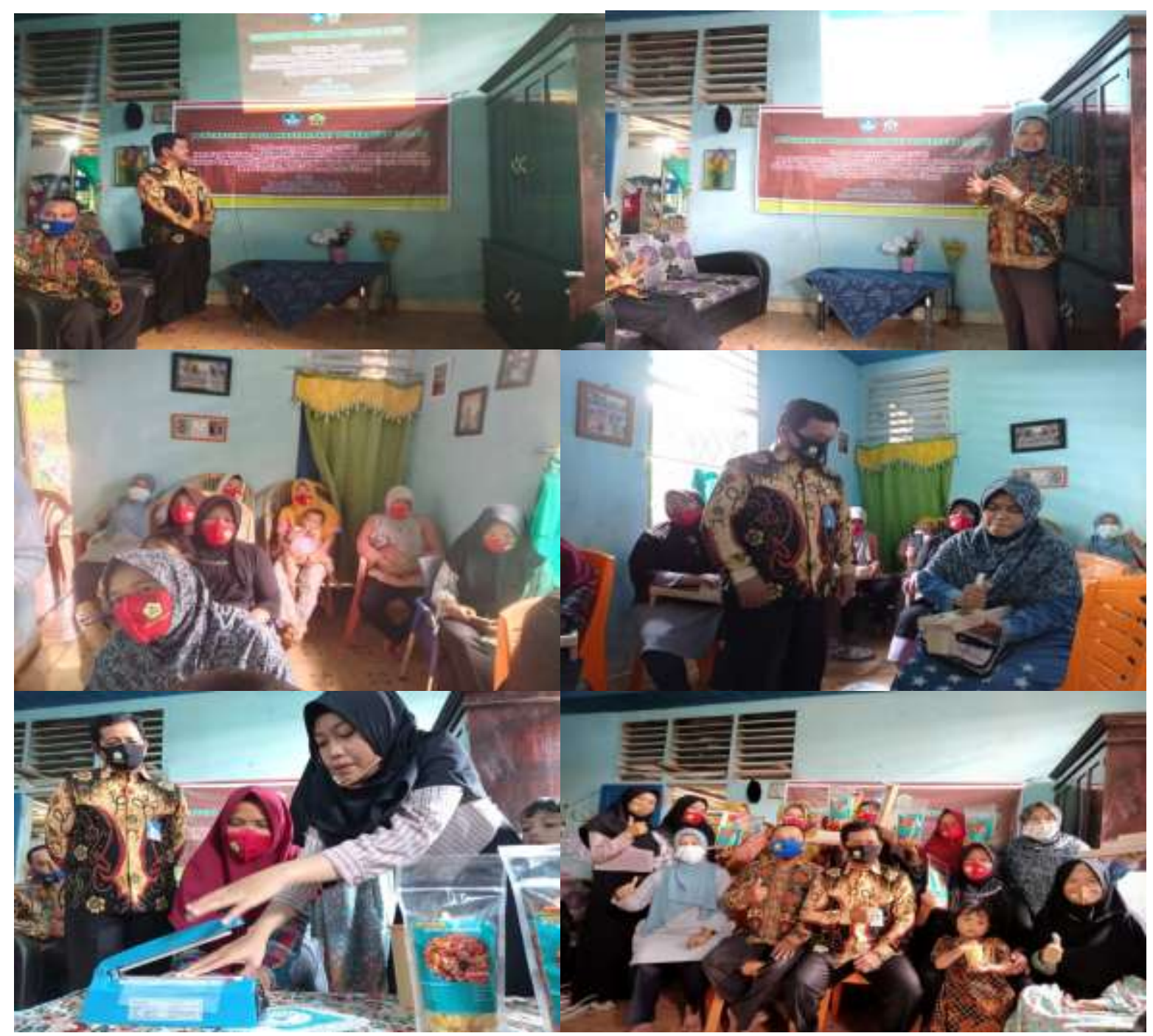

Gambar 2 Kegiatan Workshop Ekonomi Kreatif

Tahapan ketiga yaitu tindak lanjut dari hasil workshop. Kegiatan ini penting karena diharapkan ibu-ibu yang mengikuti workshop tidak hanya selesai begitu saja, tetapi ada tindak lanjutnya, sehingga ibu- ibu ditugaskan untk mencoba untuk melakukan 4P tersebut. Berikut foto-foto tindak lanjut dari hasil workshop yang dilakukan dirumah masing-masing. 


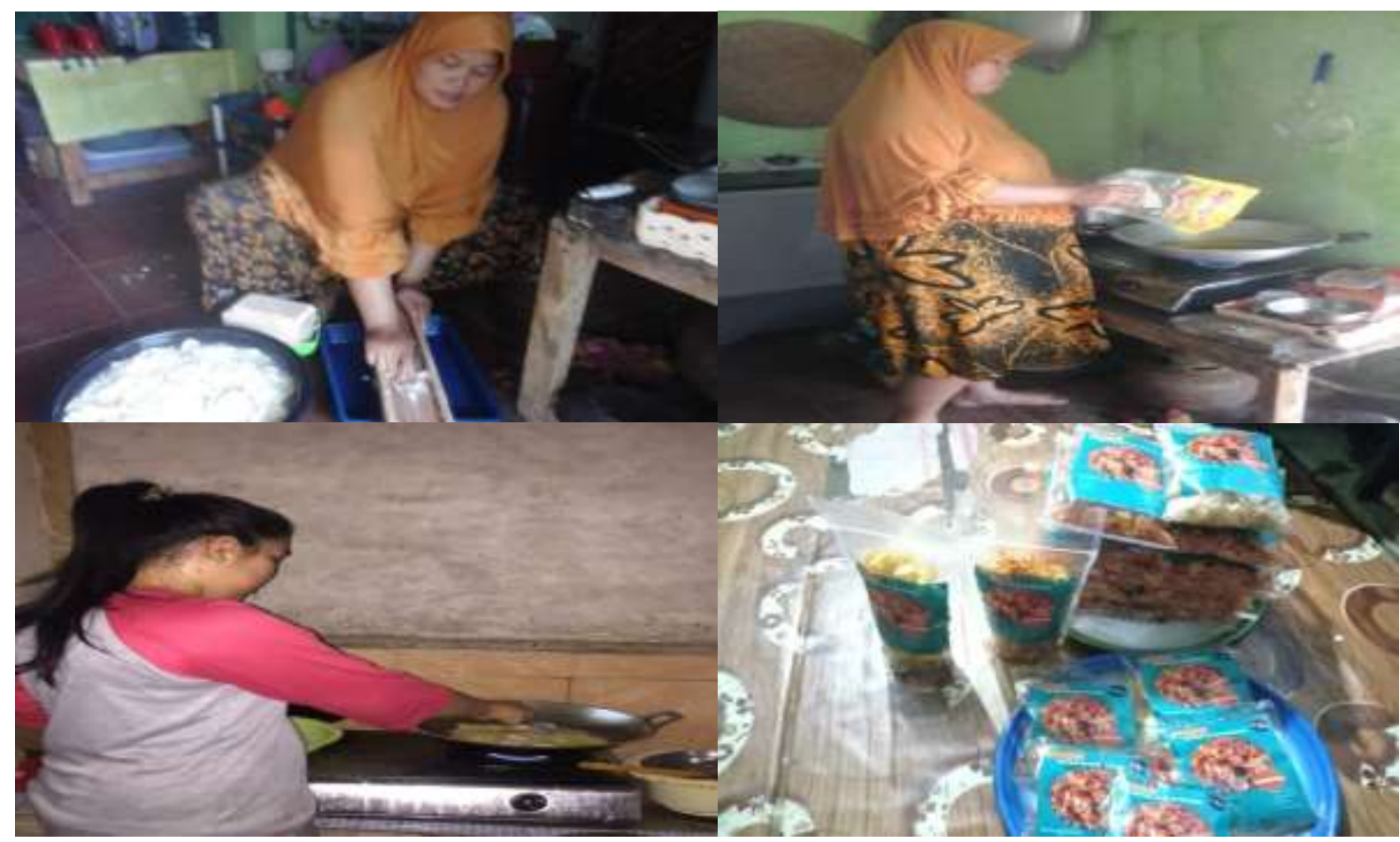

Gambar 3 Tindak Lanjut dari Hasil Workhop

Tahap terakhir yaitu Pemasaran/ Promosi online melalui FB, IG, dan WA. Media promosi online yang digunakan dalam proses marketing melalui media sosial yang terdiri dari Whatsapp Bisnis, Instagram, dan Facebook, seperti gambar berikut:

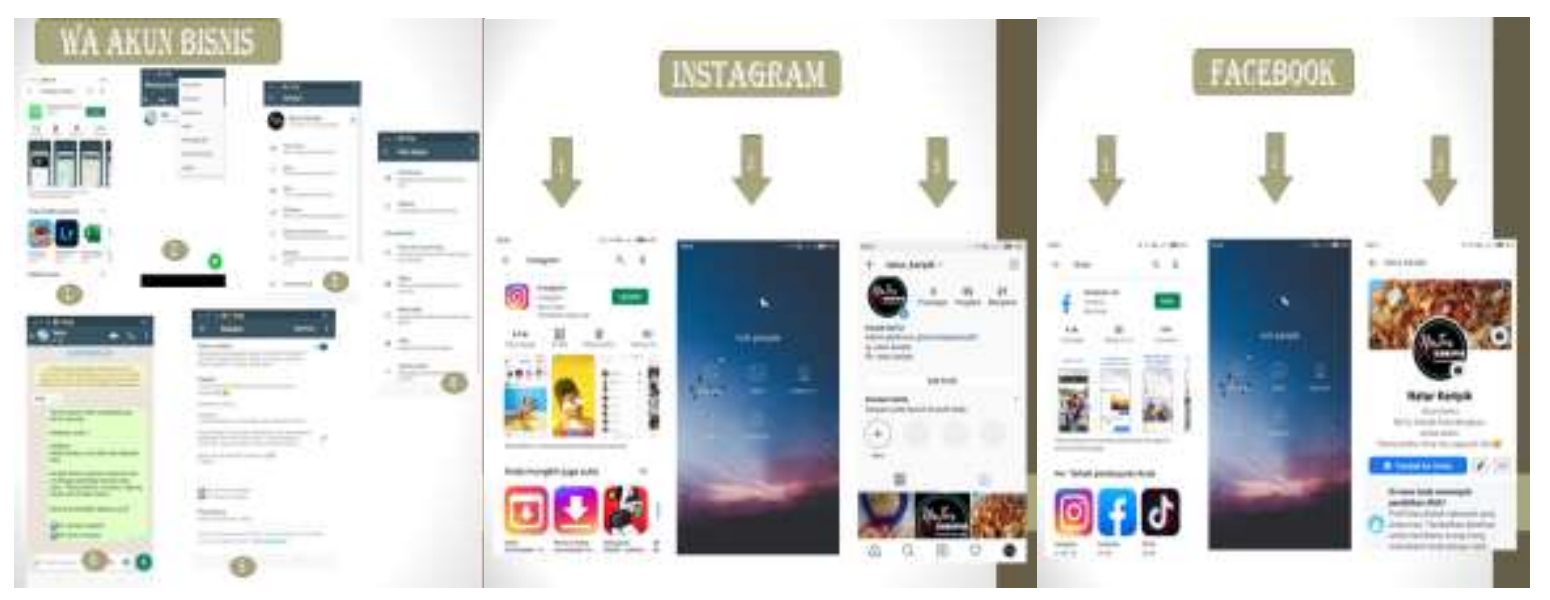

Gambar 4 Media Sosial sebagai Promosi Online 
Adalah adalah nama brand olahan semua jenis keripik adalah Natur Keripik. Berikut Gambar Brand Natur Keripik.

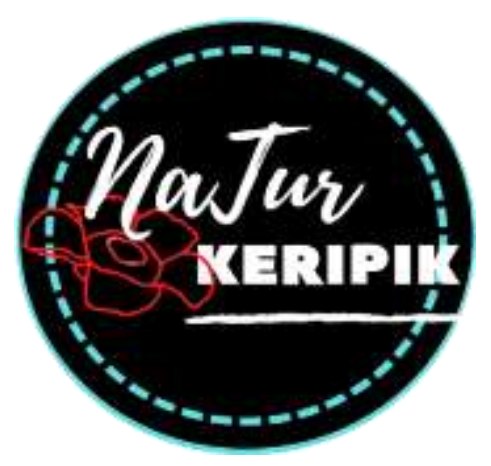

Gambar 5 Brand Natur Keripik

Melalui PPM kegiatan dilaksanakan UKM Genting Jaya terdiri pendampingan dan pembinaan, secara dari 4P yaitu Pengupasan, Pengirisan, keseluruhan tahapan pelaksanaan produksi Pengemasan dan Pemasaran, seperti dan pengolahan keripik singkong yang tersedia pada gambar berikut:
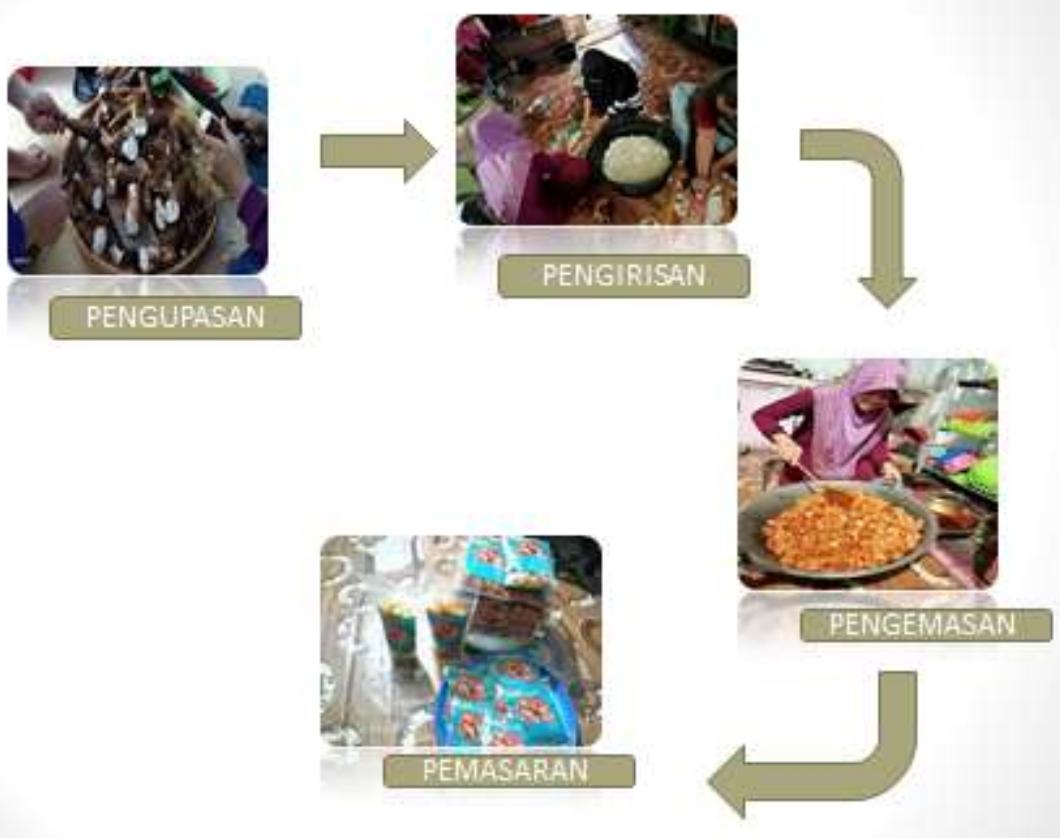

Gambar 6 Tahapan Produksi 4P Keripik Singkong Natur Keripik

\section{SIMPULAN}

Kesimpulan dari hasil kegiatan PPM ini bahwa program ini sebagai salah satu wujud tridharma perguruan tinggi yang telah memberikan manfaat bagi khalayak umum. Para ibu-ibu petani Desa Padang Bendar menjadi sasaran pengabdian dalam meningkatkan SDM nya. PPM ini memberikan workshop/ pelatihan dalam olahan singkong dengan berbagai varian rasa melalui ekonomi kreatif berbasis promosi online. Pelatihan ini memberikan dampak positif dan efektif dalam memberikan wawasan dan pengetahuan selain itu membuka jalan 
bisnis bagi petani singkong di Desa Padang Bendar, selain itu meningkatkan pemberdayaan masyarakat, dan meningkatkan kemampuan mutu SDM

\section{DAFTAR PUSTAKA}

Direktorat Pendidikan Masyarakat. (2003). Pedoman Pengelolaan dan Pembinaan Pusat Kegiatan Belajar Masyarakat. Jakarta: Depdiknas.

Eko Putro Widoyoko.( 2009). Evaluasi Program Pembelajaran: Panduan Praktis Bagi Pendidik dan Calon Pendidik. Yogyakarta: Pustaka Pelajar

Hasanah, Lak Lak Nazhat El. (2015). Pengembangan Wirausaha Muda Ekonomi Kreatif Berbasis Budaya di Daerah Istimewa Yogyakarta. Jurnal Studi Pemuda. Vol. 4. No. 2. September 2015. dalam memanfaatkan olahan singkong sehingga hasilnya bisa dirasakan langsung sebagai homemade.

Noor, Munawar. (2011). Pemberdayaan Masyarakat. Jurnal Ilmiah CIVIS. Volume I No. 2 Juli.

Sudjana, Djuju. (2006). Evaluasi Program Pendidikan Luar Sekolah: Untuk Pendidikan Nonformal dan Pengembangan Sumber Daya Manusia.Bandung: PT. Remaja Rosdakarya.

Suryana. (2013). Ekonomi Kreatif, Ekonomi Baru: Mengubah Ide dan Menciptakan Peluang.Jakarta: Salemba Empat. 